\title{
Machinery Production Networks and Import Tariff Evasion*
}

\author{
Mateus Silva Chang ${ }^{\dagger}$ \\ Research Assistant, Graduate School \\ of Economics Keio University
}

\author{
Chin-Ho Lin \\ Research Assistant, Graduate School \\ of Economics Keio University
}

\begin{abstract}
In this paper we followed Fisman and Wei's (2004) approach to estimate the effects of import tariff rates on import tariff evasion. We focus on East Asian countries import of machinery products and our main objective is to test if the trade realized inside production networks (intra-regional) is less prone to import tariff evasion than imports from countries outside it (inter-regional). In this study we considered the differences in tariff evasion between intra and inter-regional imports; parts and components and final products; and the heterogeneity between electric machinery and transport equipment. The data provide evidences that intra-regional imports are less prone to tariff evasion than inter-regional imports. Besides this, we identify differences in the channels employed to evade tariff. The results suggest that underreport of quantities was the main channel employed in intra-regional imports tariff evasion, while inter-regional import tariffs were evaded through unit price misreport.
\end{abstract}

JEL: F14, K42, H26

Key words: Tariff Evasion, Import Tariff, Machinery Production Networks, East Asia

\section{Introduction}

Import tariff evasion is an important issue, but the difficulty in directly observing it contributes to make this an understudied matter. According to Jean and Mitaritonna (2010), there are many ways to evade customs duties, including the smuggling, bribery, and fallacious declarations. Independent of the chosen method the result is a decrease in the collected tariffs. The lack of transparency and law enforcement impose difficulties for the international trade and affect countries that depend heavily on such tariffs. ${ }^{1)}$

Received 30 May 2017, Accepted 1 August 2017, Released online in J-STAGE as advance publication 20 September 2017.

* We deeply appreciate the valuable comments from Professor Fukunari Kimura, Kozo Kiyota, and Toshihiro Okubo from Keio University. This work was supported by the MEXT-supported Program for the Strategic Research Foundation at Private Universities. We also appreciate the financial aid provided by Keio Economic Society. The analysis and results presented in this research are only the responsibility of the authors.

$\dagger$ Corresponding author: Graduate School of Economics, Keio University. 2-15-45 Mita, Minato-ku, Tokyo 108-8345, Japan. E-mail: mateus.chang@keio.jp

1) According to Bausgaard and Keen's data (2009) the share of trade tax revenue in total tax receipts in 2001-2006 amounted to an average of $2.5 \%$ in high-income countries, $18.1 \%$ in middle-income countries and $22 \%$ in low-income countries. 
Machinery Production Networks and Import Tariff Evasion

Bhagwati $(1964,1967)$ produced the first studies that proposed a way to overcome the lack of available data, using the discrepancies between matched import and export declarations at product level to reveal customs duty evasion. He studied the Turkish case, identifying the existence of under-invoicing of imports, in special for manufactured products. Pritchett and Sethi (1994) analyzed customs data from three developing countries (Jamaica, Kenya, and Pakistan) and found that collected and official tariff rates were only weakly related, with variance of collected rate increasing strongly with the level of the official rate. More recently, Fisman and Wei (2004) interpreted the existence of econometrical relations between import tariff rate level and the existence of gaps between reported import and export values, what they referred to as missing imports or evasion gap, as an evidence of tax evasion. Using public available data of Hong Kong reported exports to China and Chinese reported imports from Hong Kong to quantify the effects of tax rate on tax evasion, they discovered that a one percentage point increase in the tax was associated with a $3 \%$ increase in tax evasion.

Mishra et al. (2008) analyzed the case of Indian imports and Javorcik and Narciso (2008) analyzed the imports of ten Eastern European countries from Germany, employing the same methodology as Fisman and Wei (2004). Both works contributed to the tariff evasion literature confirming the existence of a positive relation between import tariff rates and tariff evasion, and discovering that products classified as homogeneous goods, according to the Rauch classification (1999), are less vulnerable to tariff evasion than differentiated goods. According to the authors, homogeneous goods have prices that are widely known, while differentiated goods have prices that are less known and usually determined in specific transactions, creating opportunities for unnoticed misreports. Other studies performed similar exercises for different countries and periods of time. ${ }^{2}$

In a recent research Javorcik and Narciso (2017) analyzed the unintended impact that accession to the World Trade Organization (WTO) have on tariff evasion. According to their study, countries accessing the WTO have to comply with the Customs Valuation Agreement (CVA) that stipulates that customs officers cannot exercise discretion with respect to assessing values of imported goods, having to accept invoice prices. Using data for 15 countries that joined the WTO between 1996 and 2008 the authors verify that this rule effectively closed down one import tariff evasion channel (misreport of the unit value), increasing evasion through undercounting of quantities and misclassification.

The second unbundling (Baldwin, 2011) and the development of production networks, resultant from the outsourcing and offshoring processes, lead to an increase in trade of parts and components, especially in the machinery industry that is known for the use of many parts and components to assemble a final product. Given that the majority of machinery parts and components and final products are classified as differentiated goods, being more exposed to tariff evasion, and that production fragmentation increases the number of times parts and components cross borders until the final good is assemble, this paper investigates the import tariff evasion of machinery products.

Engagement on production networks presuppose production efficiency, fine harmoniza-

2) For other studies on import tariff evasion verify: Levin and Widell (2014) that analyze the tariff evasion in Kenya and Tanzania; Bouët and Roy (2012) that study the case of Kenya, Mauritius and Nigeria; Epaphra (2015) that researches the case of Tanzania; and Kume et al. (2011) that study the case of Brazil. 
tion between all production steps, and competitive costs. Consequently, tariff evasion is a very sensitive topic for this type of production organization. In other words, troubles in the customs can undermine the efficiency of production networks, given the producers exposition to unexpected extra time and monetary costs in the clearance process, attributed to bribe negotiations, plus the creation of future uncertainties.

To the best of our knowledge, the only study to approach this topic is Lin (2017) that investigated the trade of machinery final products and parts and components inside the "Factory Asia". 3) The author analyzed the import tariff impact on tariff evasion in the intra-regional trade, concluding that an increase in one percentage point of import tariff lead to an increase in tariff evasion that varies from $0.78 \%$ to $1.2 \%$. It was also verified that parts and components are more prone to suffer from tariff evasion than final products.

In this paper we complement the existing literature investigating East Asian machinery imports from countries inside and outside the "Factory Asia" in order to attest if there are differences in tariff evasion patterns. The main objective is to verify if production networks trade is less vulnerable to tariff evasion than trade with countries outside production networks. A secondary contribution is the study of import tariff evasion heterogeneity for different machinery sectors. We decompose the machinery trade focusing on the main machinery sectors: electric machinery and transport equipment. The rest of this paper is organized as follows: section 2 reports the database construction. Section 3 briefly exposes some summary statistics and trends of tariff rates and tariff evasion gap. Section 4 explains how we set the model, while section 5 presents the results, section 6 robustness check exercises, and section 7 the concluding remarks.

\section{Data}

In this study we use data collected from two main sources. The first one is the World Integrated Trade Solution (WITS) that provides different schemes of import tariffs based on UNCTAD's Trade Analysis and Information System (TRAINS) database. This source provides detailed tariff information, such as importer, exporter, year of trade, product imported and tariff rate at the Harmonized System (HS) 6-digit level. We use the available applied tariffs data and complement our database with the value of the nearest year (preference is given to previous year data) to replace missing tariffs. The analyzed period covers different versions of HS classification. The products code might slightly change depending on the specific HS version. To address this problem, we use a conversion table to convert all variations to the HS1992 classification.

The second source is the United Nations Commodity Trade Statistics Database (UN Comtrade) that provides HS 6-digit level trade data. Following Lin (2017), we use the recorded imports of eleven East Asian countries ${ }^{4}$. Exporters are limited to 93 countries $^{5)}$ that comprise

3) According to Athukorala (2011) the East Asian region is the most outstanding example of machinery production networks due to deeper and wider intra-regional trade of machinery parts and components.

4) East Asia in this paper is composed by the countries from ASEAN+3 (Brunei, Cambodia, Indonesia, Lao PDR, Malaysia, Myanmar, Singapore, the Philippines, Thailand and Vietnam plus China, Japan and South Korea), excluding Lao PDR from the sample due to data limitation. Although Hong Kong is also part of East Asia, its data is used only when it appears as an exporter to other East Asian countries. The same applies to Singapore, given that the import tariff of these two countries are zero for all machinery products.

5) The list containing the 93 countries divided by regions is available in the Appendix. 
Machinery Production Networks and Import Tariff Evasion

around $99.5 \%$ of East Asian countries import value in 2011. Import values recorded by East Asian countries and export values recorded by exporter countries are all classified according to HS1992 classification. Following the literature, we match these data and drop products that have missing values on one of the sides.

Given data availability, the analysis covers the period from 1996 to 2011. Machinery industry is comprised by all the goods categorized as general machinery sector (HS84), electric machinery sector (HS85), transport equipment sector (HS86-89), and precision machinery sector (HS90-92). These products are classified as parts and components and final products according to Kimura and Obashi (2010) classification.

\section{Import tariff rates, trade gap, and machinery sector: a descriptive analysis}

In this paper we focus on the relationship between import tariff rate and tariff evasion for the East Asian countries intra and inter-regional import of machinery products. Our objective is to examine whether the business environment created by the development of machinery production networks inside East Asia leads to lesser import tariff evasion than in imports from countries outside these production networks. In this exercise we consider the differences in tariff evasion between parts and components and final products. We also analyze the differences in tariff evasion between the two main machinery sectors: electric machinery and transport equipment.

To perform the mentioned exercises we define trade gap following Fisman and Wei (2004). Trade gap is defined as the log difference between the value of exports recorded by the exporting country and the value of imports recorded by the importing country. The gap is calculated at the 6-digit level HS product for each exporter-importer pair and year. According to Epaphra (2015) a discrepancy between the recorded values is to be expected, because the export values are expressed in FOB (free on board) terms, while imports are recorded in CIF (including the cost, insurance and freight). Intuitively, values in CIF should be higher than values in FOB. Besides this, countries tend to monitor imports more carefully than exports, consequently, in the absence of tariff evasion one would expect the difference to be negative. If the gap is positive, that suggests a possible presence of tariff evasion. The trade gap is defined as follows:

$$
\text { gap_value }_{i j k t}=\ln \left(\text { Export }_{\text {value }}\right)_{\substack{i, \text { record } \\ \text { ijkt }}} \ln \left(\text { Import }_{\text {value }}\right)_{i j k t}^{j, \text { record }}
$$

where country $i$ exports to country $j$ the product $k$ in year $t$. The notations $i$, record and $j$, record represent exports recorded by an exporting country and imports recorded by an importing country, respectively.

The distribution of East Asian countries imported machinery products import tariff rates are shown in Figure 1. The variation in the import tariff rates is low, with a concentration of products around zero tariff rate achieving almost 40\%. Since zero tariff products account for more than one-third of all machinery products (approximately $34.7 \%$ ), we examine if there is a significant difference on trade gap between zero import tariff and non-zero import tariff products. It is expected that the lower the tariff rate the smaller would be the incentive for importers and corrupt customs officers to evade import tariff, while for zero tariff products this 
Figure 1: Distribution of East Asian countries HS 6-digit level machinery products import tariff rates

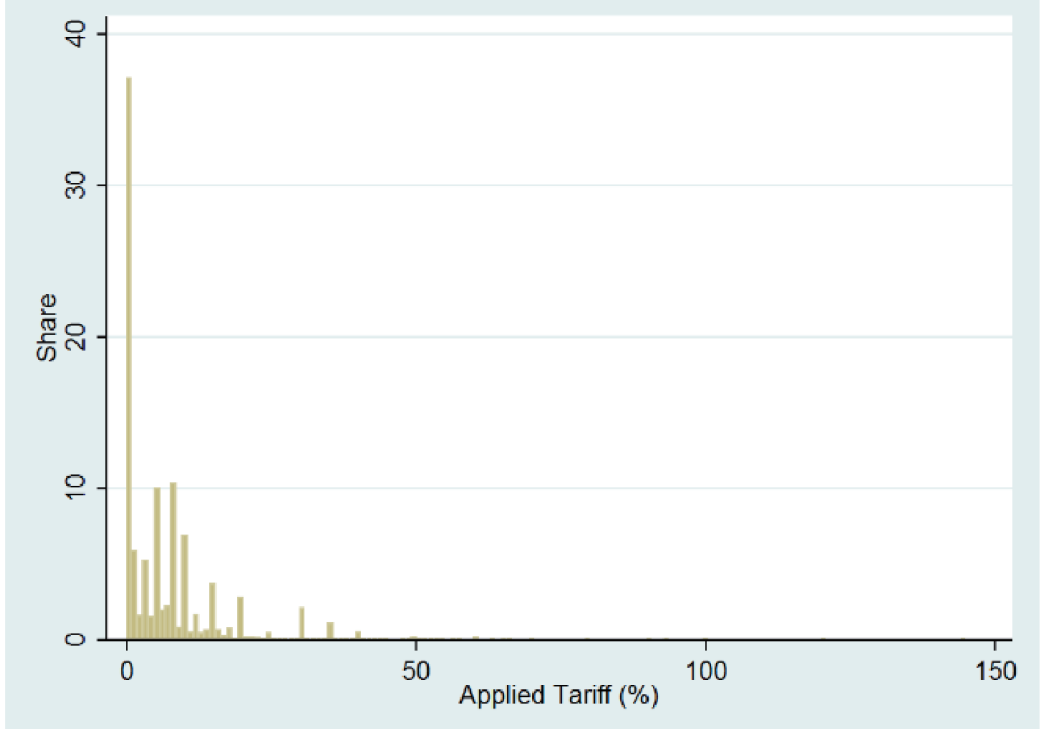

incentive should be almost null. ${ }^{6}$ )

Table 1 shows the summary statistics for the evasion gap ${ }^{7)}$ of products with zero and nonzero import tariff levels. As expected, products whose tariff rates are zero have lower evasion gap than products whose tariff rates are larger than zero. In fact, the products with zero tariff have a negative mean, indicating none or very small levels of tariff evasion. Decomposing the machinery imports in final products and parts and components we identify a similar pattern: zero tariff products have a negative mean, while non-zero tariff products have a positive mean. In particular, parts and components evasion gap mean is smaller than final products one for zero and non-zero tariff products, indicating a smaller probability of tariff evasion. The results suggest that the evasion gap magnitude can have some relation with the type of products and the level of tariff rates.

Next, we disaggregate the data and perform the same exercise for the main machinery sectors: electric machinery and transport equipment. Since zero tariff products are less prone to tariff evasion, we focus on non-zero tariff products. Table 2 contains both machinery sectors summary statistics. The first thing we observe is that electric machinery products seem to be less prone to tariff evasion than transport equipment, since the mean of the latter is higher than the former. Besides this, final electric products seem to be more exposed to tariff evasion. On the other hand, transport equipment descriptive analysis indicates the opposite: parts and components are more prone to tariff evasion.

As our main objective is to verify the differences in trade inside and outside the "Factory

6) The existence of other types of tax, like the VAT, and non-tariff barriers can also be interpreted as minor incentives to customs evasion and positive trade gaps.

7) In this paper we refer to evasion gap and trade gap as synonyms. 
Machinery Production Networks and Import Tariff Evasion

Table 1: Trade gap summary statistics of zero and non-zero import tariff products

\begin{tabular}{lcccrcc}
\hline Zero tariff products & Mean & Median & SD & Min & Max & Observations \\
\hline All & -0.071 & -0.033 & 2.221 & -16.758 & 15.375 & 750379 \\
P\&C & -0.130 & -0.055 & 2.307 & -16.758 & 15.335 & 371434 \\
Final & -0.012 & -0.016 & 2.131 & -16.238 & 15.375 & 378945 \\
\hline Non-Zero tariff products & Mean & Median & SD & Min & Max & Observations \\
\hline All & 0.095 & 0.017 & 2.248 & -15.323 & 15.583 & 570087 \\
P\&C & 0.075 & 0.022 & 2.292 & -15.323 & 15.583 & 343492 \\
Final & 0.126 & 0.013 & 2.179 & -14.583 & 13.054 & 226595 \\
\hline
\end{tabular}

Table 2: Trade gap summary statistics of non-zero import tariff products according to machinery sector

\begin{tabular}{lrrcccc}
\hline Electric Machinery & Mean & Median & SD & Min & Max & Observations \\
\hline All & 0.038 & -0.014 & 2.366 & -14.583 & 14.875 & 193378 \\
P\&C & -0.038 & -0.051 & 2.377 & -14.193 & 14.875 & 130771 \\
Final & 0.196 & 0.063 & 2.335 & -14.583 & 12.897 & 62607 \\
\hline Transport Equipment & Mean & Median & SD & Min & Max & Observations \\
\hline All & 0.247 & 0.076 & 2.394 & -12.849 & 12.661 & 15122 \\
P\&C & 0.262 & 0.109 & 2.512 & -12.849 & 12.661 & 9560 \\
Final & 0.222 & 0.035 & 2.177 & -11.282 & 10.444 & 5562 \\
\hline
\end{tabular}

Table 3: Trade gap summary statistics of non-zero import tariff products according to exporter region

\begin{tabular}{lcccccc}
\hline Intra-regional & Mean & Median & SD & Min & Max & Observations \\
\hline All & 0.250 & 0.103 & 2.282 & -15.323 & 15.583 & 186737 \\
P\&C & 0.245 & 0.115 & 2.345 & -15.323 & 15.583 & 106489 \\
Final & 0.258 & 0.091 & 2.196 & -14.583 & 12.897 & 80248 \\
\hline Inter-regional & Mean & Median & SD & Min & Max & Observations \\
\hline All & 0.020 & -0.019 & 2.228 & -13.620 & 13.838 & 383350 \\
P\&C & -0.001 & -0.018 & 2.264 & -13.620 & 13.838 & 237003 \\
Final & 0.054 & -0.020 & 2.167 & -12.654 & 13.054 & 146347 \\
\hline
\end{tabular}

Asia", we disaggregate the data in intra and inter-regional imports. Our hypothesis is that intra-regional mean evasion gap would be smaller than the inter-regional one, however the summary statistics in Table 3 reveals the opposite pattern with inter-regional evasion gap mean being smaller. Although the descriptive analysis result do not corroborate with the hypothesis that intra-regional trade is less prone to tariff evasion, one needs to analyze carefully this 
result. As already mentioned, our main interest is not identifying the trade gap per se, since these results also involve possible measurement errors, misclassification involving re-exports, and other discrepancies that are not necessarily related to tariff evasion. Consequently, we still need to perform some econometrical exercises to verify the existence or not of a statistical relation between import tariff rate and trade gap for different groups sorted according to the above mentioned characteristics.

In the next section we present the methodology and model employed to perform econometrical exercises that test if the summary statistics results hold.

\section{Empirical strategy}

As highlighted in the previous section, just the analysis of the trade gap per se does not constitute a conclusive evidence, given the existence of measurement errors and other factors mentioned before. A stronger evidence of corruption would be the existence of a systematic relationship between import tariff level and tariff evasion, reflecting not random, but intentional misreports. In accordance with the previous literature, we model this relationship and use fixed effects to control for importer-year, exporter-year and product specific characteristics. ${ }^{8)}$ Intra-regional dummy and an interaction term of this dummy and tariff level was added to capture possible differences between tariff evasion inside and outside production networks. For the most detailed specification we also control for differences between parts and components and final products adding a parts and components dummy, an interaction between this dummy and the tariff level, and an interaction between tariff level, intraregional and parts and components dummy:

$$
\begin{aligned}
& \text { gap_value }_{i j k t}=\ln \left(\text { Export }_{\text {value }}\right)_{i j k t}^{i_{i j k} \text { record }}-\ln \left(\text { Import }_{\text {value }}\right)_{i j k t}^{j, \text { record }}=\beta_{0}+\beta_{1} \text { Tariff }_{j i k t} \\
& +\beta_{2} \text { Tariff }_{\text {jikt }} * \text { intraregional }_{i}+\beta_{3} \text { intraregional }_{i}+\beta_{4} \text { Tariff }_{j i k t} * P C_{k}+\beta_{5} P C_{k} \\
& +\beta_{6} \text { Tariff }_{j i k t} * \text { intraregional }_{i}^{*} P C_{k}+\theta_{i t}+\pi_{j t}+\mu_{k}+\varepsilon_{i j t k}
\end{aligned}
$$

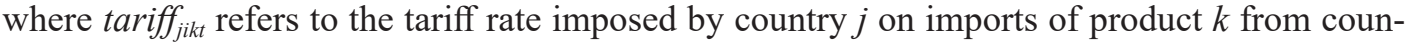
try $i$ at year $t$; intra-regional ${ }_{i}$ is a dummy that has the value of one if the exporter $i$ is an East Asian country; $P C_{k}$ is a dummy that has the value of one if the traded product $k$ is a part or component; $\theta_{\text {it }}$ is a vector of fixed effects for exporter-year that controls for changes in exporter policies; $\pi_{j t}$ is a vector of fixed effects for importer-year countries that controls for changes in importer policies; and $\mu_{k}$ is a vector of HS 6-digit product fixed effects that controls for time-invariant factors on particular products.

If evasion induced by tariff rate is prevalent, we expect $\beta_{1}>0$, like in the previous literature. Our main interest is in $\beta_{2}$ that explains the evasion with respect to the tariff rates in the case of imports inside the East Asian production network. It is expected that $\beta_{2}<0$, indicating that production network imports are less prone to tariff evasion.

According to the literature, there are three different forms of evading import tariffs. The first way is undercounting the physical quantities of imported products, while the second channel is through the misreport of the imported products unit value. These two forms of evading tariffs are accounted in the following specifications:

8) Following the literature we also cluster the standard errors at the 6-digit product level to account for potential serial correlation of evasion for a particular product. 


$$
\begin{aligned}
& \text { gap_quantity }_{i j k t}=\ln \left(\text { Export }_{\text {quantity }}\right)_{i j k t}^{i, \text { record }}-\ln \left(\text { Import }_{\text {quantity }}\right)_{i j k t}^{j, \text { record }}=\beta_{0}+\beta_{1} \text { Tariff }_{j i k t} \\
& +\beta_{2} \text { Tariff }_{\text {jikt }} * \text { intraregional }_{i}+\beta_{3} \text { intraregional }_{i}+\beta_{4} \text { Tariff }_{\text {jikt }} * P C_{k}+\beta_{5} P C_{k} \\
& +\beta_{6} \text { Tariff }_{\text {jikt }} * \text { intraregional }{ }^{*} P C_{k}+\theta_{i t}+\pi_{j t}+\mu_{k}+\varepsilon_{j i t k} \\
& \text { gap_unitprice }_{i j k t}=\ln \left(\frac{\text { Export }_{\text {value }}}{\text { Export }_{\text {quantity }}}\right)_{i j k t}^{i, \text { record }}-\ln \left(\frac{\text { Import }_{\text {value }}}{\text { Import }_{\text {quantity }}}\right)_{i j k t}^{j, \text { record }}=\beta_{0}+\beta_{1} \text { Tariff }_{\text {jikt }} \\
& +\beta_{2} \text { Tariff }_{j i k t} * \text { intraregional }_{i}+\beta_{3} \text { intraregional }_{i}+\beta_{4} \text { Tariff }_{j i k t} * P C_{k}+\beta_{5} P C_{k} \\
& +\beta_{6} \text { Tariff }_{\text {jikt }} * \text { intraregional }{ }^{*} P C_{k}+\theta_{i t}+\pi_{j t}+\mu_{k}+\varepsilon_{j i t k}
\end{aligned}
$$

The third channel is through mislabeling or misclassification of similar products. According to Fisman and Wei (2004), a misclassification between similar products happens when a higher-taxed product is reported as a lower-taxed variety. The authors proposed that products can be consider similar if they are classified under the same 4-digit HS code. They control for tariffs on similar products by including in the model the weighted average tariff of the products similar to $\mathrm{k}\left(\mathrm{w} \_\right.$avg $\left.\left(\operatorname{Tariff}_{\mathrm{jikt}}\right)\right)$ :

$$
\text { gap_value }_{i j k t}=\beta_{0}+\beta_{1} \text { Tariff }_{j i k t}+\beta_{2} \mathrm{w} \_a v g\left(\text { Tariff }_{\mathrm{jikt}}\right)+\theta_{i t}+\pi_{j t}+\mu_{k}+\varepsilon_{i j k t}
$$

In the presence of goods misclassification it is expected that $\beta_{2}<0$, meaning that when the own product tariff rate is held constant, the lower the weighted average tariff rate of the similar products the higher will be the incentive to misclassify product $k$ as one of its similar.

\section{Estimation results}

\subsection{Trade gap, quantity gap, unit price gap, and mislabeling}

Our first exercise is to estimate the models presented in the previous section. As highlighted in section 3, almost $35 \%$ of the variety of imported machinery products have a zero import tariff. Provided that products with zero import tariff are less prone to trade evasion, based on the lack of incentives to incur in illegal actions, just non-zero tariff products will be considered in this investigation. The outcome for the estimations of trade value gap are reported in columns 1-4 in Table 4 . The first thing we observe is if the estimated $\beta_{1}$ is positive and statistically significant for machinery products, what would be an evidence of tariff evasion. Column 1 reveals that a one percentage point increase in the tariff rate is associated with an increase in the trade gap of $0.6 \%$. In the next column we test if mislabeling is one of the channels used to evade tariffs by adding the weighted average tariff on similar products. ${ }^{9}$ Once again the tariff coefficient is positive and statistically significant, while the weighted average tariff on similar products coefficient is negative and statistically significant at the $10 \%$ level, providing a weak evidence that mislabeling could be a secondary channel used to evade tariffs. In the next column we test for the difference in intra and inter-regional trade by adding a dummy variable that assumes the value of one when imports are from East Asian countries and an interaction of this dummy with the tariff variable. The interaction term reveals how the marginal effects of intra-regional imports differ from the marginal effects of inter-regional imports. To facilitate the analysis of the results in the lower part of the table we report the

9) To calculate the weighted average tariff of similar products it is necessary data of at least one similar product. Consequently, products without a similar product are dropped from the estimation, slightly decreasing the number of observations. 
M.S. Chang and C.H. Lin

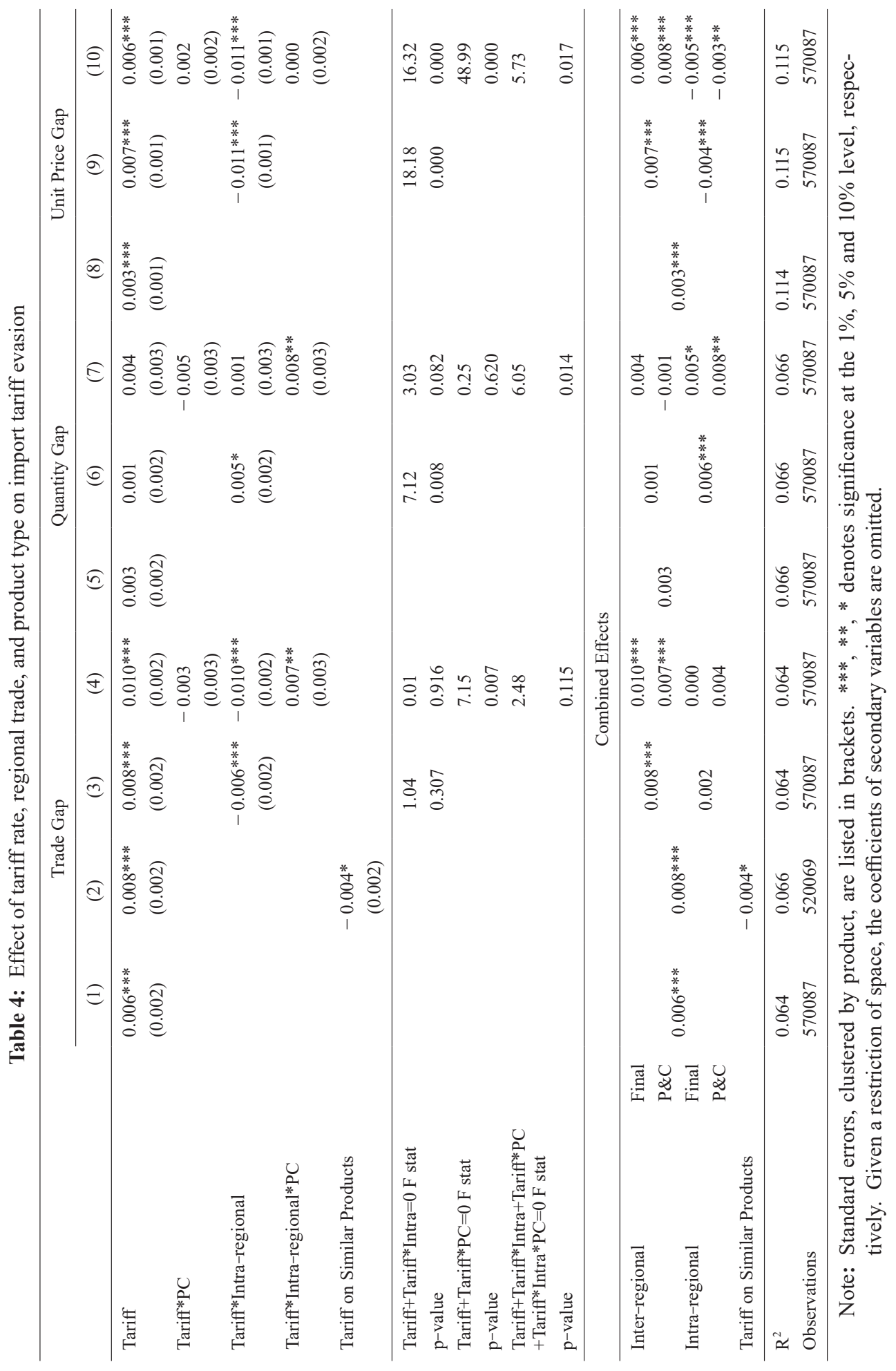


Machinery Production Networks and Import Tariff Evasion

combined marginal effects. The tariff coefficient is still statistically significant and positive, indicating the presence of intentional tariff evasion in inter-regional imports. On the opposite side, the result from the sum of the tariff coefficient and the interaction of tariff and intraregional trade coefficient is positive and smaller, indicating that machinery intra-regional imports are less prone to tariff evasion than inter-regional ones. According to the results in column 3 a one percentage point increase in the tariff rate is associated with an increase in the trade gap of $0.8 \%$ for inter-regional imports and $0.2 \%$ for intra-regional imports. However, the $\mathrm{F}$ statistic is not statistically different from zero in the intra-regional imports case, indicating the inexistence of intentional tariff evasion in intra-regional imports. Finally, in the fourth column a dummy for parts and components as well as the necessary interactions were added in order to identify the differences between parts and components and final products tariff evasion. Results reveal that a one percentage point increase in the tariff rate is associated with an increase in the trade gap of $1.0 \%$ in inter-regional imports of final products, $0.7 \%$ in interregional imports of parts and components, and $0.4 \%$ in intra-regional imports of parts and components. Again the F statistic is not statistically different from zero in intra-regional imports of final products and parts and components. These initial results indicate that machinery inter-regional trade suffers with tariff evasion, while the same does not apply to intraregional trade.

In order to identify each channel contribution to tariff evasion, columns 5-10 present the results for quantity gap and unit price gap. The majority of the tariff coefficients in columns 5-7 are statistically insignificant, indicating that quantity underreport is not the main channel used to evade tariffs. In column 6 we find evidences that underreport of quantities was employed to evade tariffs in intra-regional imports. In the next column the intra-regional imports are separated in parts and components and final products, with parts and components coefficient being positive and statistically significant at the $5 \%$ level, while final products one is positive, but smaller and statistically significant at $10 \%$ level. Evidences were found that a one percentage point increase in parts and components import tariff leads to an increase of $0.8 \%$ in the quantity gap, while weak evidences indicate that a one percentage point increase in final products import tariff leads to an increase of $0.5 \%$ in the quantity gap. This result indicates that trade evasion through the misreport of traded quantities is constrained to the intraregional trade of machinery and more specifically to parts and components.

Columns 8-10 report the coefficients considering the unit price gap. Tariff coefficients are all statistically significant and positive. The coefficient in column 8 indicates that a one percentage point increase in the tariff leads to an increase in the unit price gap of $0.3 \%$. The interaction between intra-regional dummy and tariff in column 9 has a negative coefficient, indicating that intra-regional trade is less prone to tariff evasion than inter-regional trade. Coefficients in column 10 indicate that a one percentage point increase in the tariff leads to an increase in the unit price gap of $0.6 \%$ in inter-regional trade of final products, $0.8 \%$ in interregional trade of parts and components, and declines in intra-regional unit price gap of $0.5 \%$ for final products and $0.3 \%$ for parts and components. In fact, the negative coefficients in columns 9 and 10 provide an unexpected and counter-intuitive result. There are two possible explanations for these results. Kellenberg and Levinson (2016) pointed out that tariff evasion is a product of the interaction of two offsetting forces: the higher the tariffs the more incentive will exist for the importer to evade the tariff and for the government to accurate report the 
imports and collect the tariffs. Consequently, it is possible that increases in tariff rate generate decreases in tariff evasion. Another cause is related to the fact that country-product level tariff data cannot account for the existence and use of export processing zone schemes. These schemes allow for the exemption of import tariffs in cases when machineries and parts and components are imported and used, inside specific geographical zones, in the production of goods that will supply the external market. Consequently, for these cases the nominal tariff is positive, but in reality the importer pays no import tariff, having no incentive to evade tariffs. This bias decreases the values of the coefficients. Therefore, instead of focusing on the absolute values of the coefficients we are more interested in the existence of statistically significant relationship between import tariff rate and evasion gap, an evidence of tariff evasion, and the relative values of these coefficients.

Results in this subsection revealed that, in general, intra-regional imports are less prone to tariff evasion than inter-regional imports. The engagement in production networks presuppose efficiency and low cost of production. Thus, the existence of bureaucracy and corruption in the customs can be a hindrance to the engagement on it. Consequently, the creation of the business environment necessary to participate in production networks, resultant from agreements and other tacit measures that complement the decrease in import tariffs, should favor tariff evasion reduction in intra-regional trade. Another interesting feature is related to the difference in channels used to evade tariff in the intra and inter-regional cases. In the former case, underreport of quantities was the main channel employed, while in the later the underreport of unit price was the adopted channel. Given that customs are the same for both types of imports, the results reflect the existence of differences between imports inside and outside the production networks. Provided that production network members promote large volumes and high frequency trade, it is expected that customs officers are more used to the correct unit price of these imported products. However, opening the containers, inspecting how many items were imported and the weight of each imported variety, especially in the case of tiny parts and components, is a more complicated task to perform. These facts could explain the difference in channels adopted to evade tariffs in intra and inter-regional trade.

\subsection{Trade gap, quantity gap, unit price gap, and mislabeling by machinery sector}

In this subsection our interest is to use the heterogeneity between machinery sectors to analyze if the previous results depend or not on the machinery characteristics. We restrict our study to the two most important sectors of machinery: electric machinery and transport equipment. Based on the physical characteristic of each sector's parts and components (electric machinery ones tend to be tinier than the transport equipment ones) we can test if the practice of underreporting imported quantities is more common for one type of machinery than the other.

Following the same pattern of the previous subsection, Tables 5 and 6 present electric machinery and transport equipment results. Columns 1-2 in Table 5 reveal a weak relationship between tariff and trade evasion for electric machinery, while mislabeling coefficient is statistically insignificant. In column 3 the tariff coefficient is positive and statistically significant in the inter-regional imports, while the F statistic reveals no statistically significant relation in the intra-regional imports. Results in column 4 indicate the existence of a statistically significant relation between tariff and trade evasion just in inter-regional imports of electric machinery 
Machinery Production Networks and Import Tariff Evasion

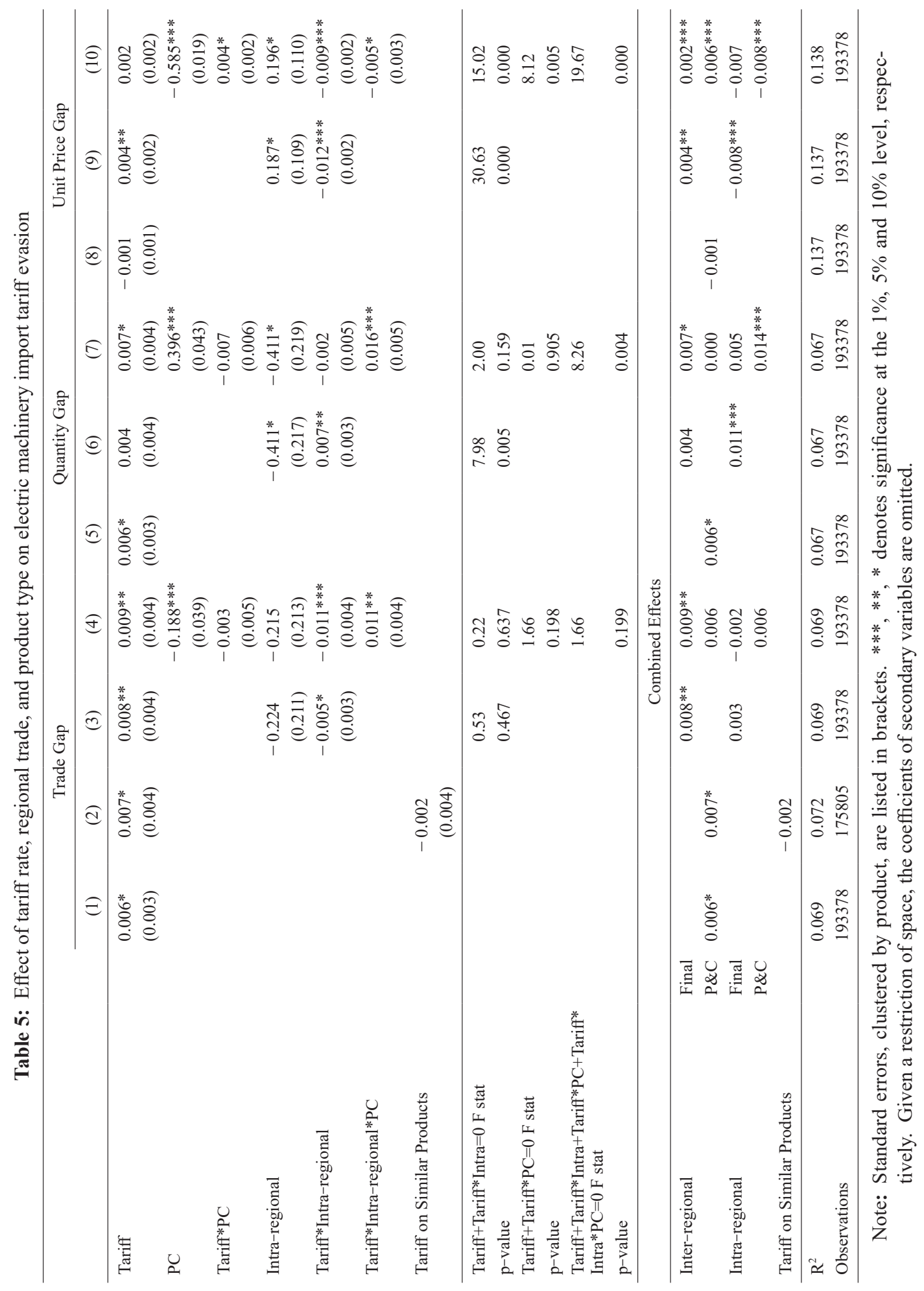


final products. A one percentage point increase in the tariff leads to an increase in the trade gap of $0.9 \%$ in inter-regional trade of final products. The F statistic reveals that there is no statistically significant relation between tariff and trade gap for intra and inter-regional imports of parts and components.

Columns 5-7 focus on the quantity gap. In column 5 the tariff coefficient is positive and statistically significant at the $10 \%$ level, indicating the existence of a weak relation between tariff level and tariff evasion. In the next column the inter-regional tariff coefficient is statistically insignificant, while the intra-regional one is statistically significant at the $1 \%$ level. In column 7 we identify that a one percentage point increase in the tariff of electric machinery leads to an increase in the quantity gap of $1.4 \%$ for intra-regional trade of parts and components. The coefficient for the inter-regional trade of final products is statistically significant, but at the $10 \%$ level, indicating a remote possibility of tariff evasion through quantity underreport, while no statistical relation is found for inter-regional trade of parts and components and intra-regional trade of final products.

Next, in columns 8-10 we focus on the unit price gap. In column 9 we observe that the coefficient for the tariff is positive and statistically significant, while the combined marginal effect for intra-regional imports is negative and statistically significant, indicating that interregional trade of electric machinery is more prone to tariff evasion through misreport of unit price. In column 10 the results indicate that evasion through misreport of unit price is a practice more common in inter-regional trade of parts and components, followed by inter-regional import of final products and intra-regional import of parts and components.

From the electric machinery results we can conclude that intra-regional trade of electric machinery is less prone to tariff evasion. We also observe that unit price misreport is the main channel used to evade import tariffs in the inter-regional trade, while the electric machinery parts and components intra-regional trade evasion occurs mainly through the misreport of traded quantities.

According to our hypothesis the intra-regional tariff evasion through quantity underreport was possible for electric machinery parts and components, because they are small and numerous, being harder of keeping track of the correct imported quantities. Nevertheless, if this fact is correct we expect that intra-regional imports of transport equipment should be less exposed to tariff evasion through quantity underreport, given that parts and components in this sector are in general big and consequently easier to be tracked. Table 6 exposes the results for transport equipment. The first four columns reveal that no statistically significant relation was found for the tariff coefficient. In column 2 the coefficient for tariff on similar products is statistically significant at the $5 \%$ level, revealing that mislabeling could be a channel used to evade tariffs. In the columns referent to quantity gap all coefficients of interest are statistically insignificant or the F statistic reveals that the relations are not statistically different from zero. The exception is the coefficient for the inter-regional import of final products that is weakly statistically significant and negative. From these columns we can conclude that misreport of quantity is hardly a channel used to evade transport equipment import tariff. In the last two columns of the table we identify evidences of tariff evasion in transport equipment. In column 9 the tariff coefficient is statistically significant and positive at the $5 \%$ level for the interregional import of final products, while the coefficient for the interaction of tariff and intraregional trade dummy is negative and statistically significant at the $1 \%$ level. In the next 


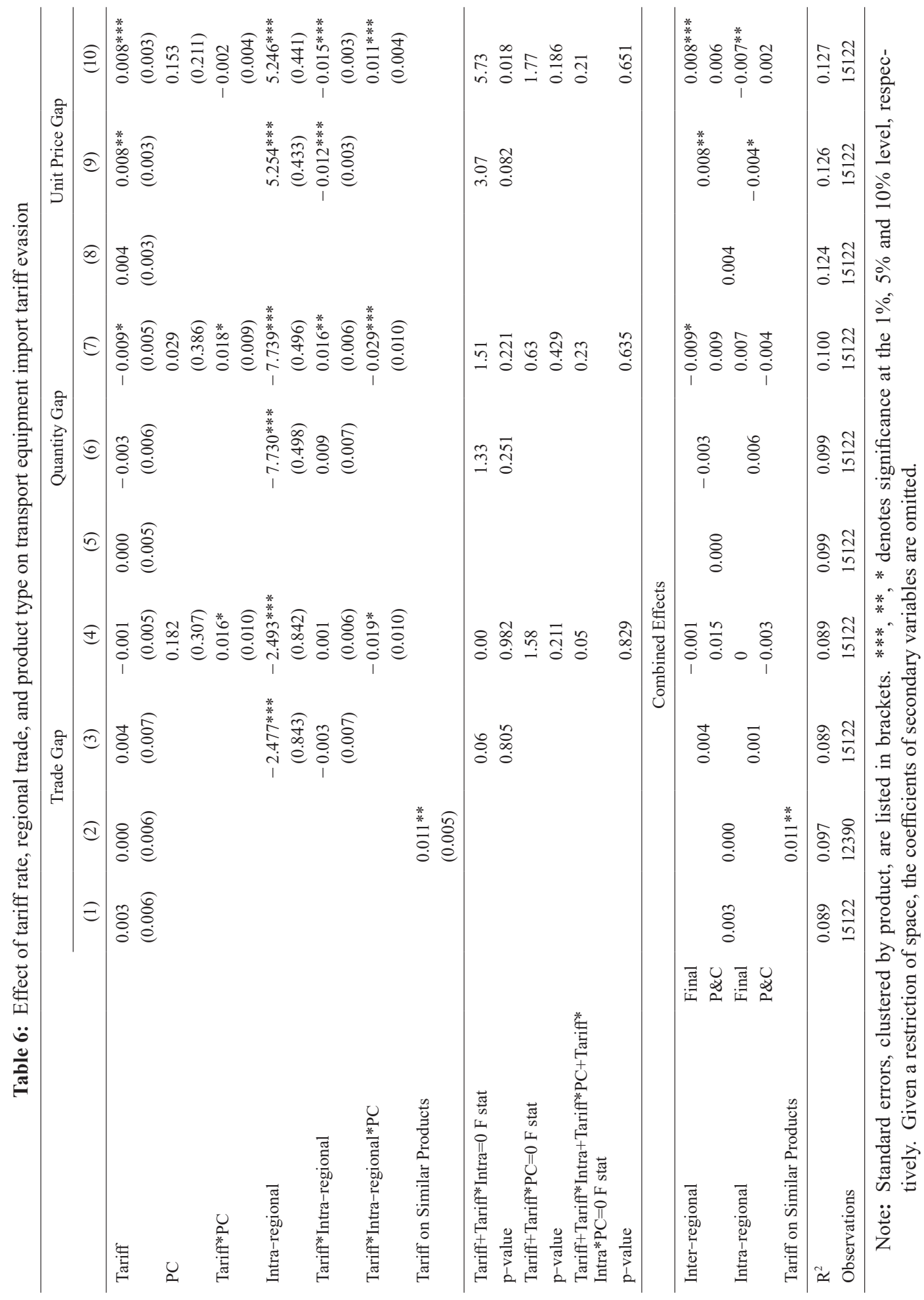


column the coefficients reveal that inter-regional imports of final products are exposed to tariff evasion, being positive and statistically significant at the $1 \%$ level. On the opposite side, the coefficient for intra-regional import of final products is negative, but statistically significant at the $5 \%$ level. The coefficients for inter and intra-regional import of parts and components are statistically insignificant.

The results for transport equipment reveal that, compared to electric equipment, this sector hardly suffers with tariff evasion. Evidences were found of imports of final products being exposed to tariff evasion through unit price misreport. No evidences were found that intraregional imports, in special the parts and components one, suffer with tariff evasion through the quantity misreport channel.

This subsection confirms that intra-regional trade is less prone to tariff evasion than interregional trade. The disaggregation of the data in parts and components and final products by machinery sector confirms that misreport of unit price is the main channel used to evade tariffs in inter-regional imports. On the intra-regional imports case we also found some evidences of unit price misreport and strong evidences of quantity misreport for electric machinery parts and components, corroborating the proposed hypothesis.

\section{Robustness check}

\subsection{Production network products dummy}

In the previous section it was analyzed the impact of import tariff rates on import tariff evasion depending on characteristics such as intra or inter-regional trade, the type of product (parts and components or final product), and machinery sector. The main objective of these exercises was to verify if trade related to production networks is less prone to tariff evasion or not. In this subsection we address the same question employing a more refined definition to separate the data in products with higher probability of being part of production networks and a group of non-production network products. Based on the definition of production networks we expect that countries engaged on it maintain stable and intensive trade flows of given products, what allow us to propose two definitions of production network dummies. In the less stringent one a dummy assumes value of one when there is a stable and intensive trade relation involving intra-regional countries. In other words, a given country must import a given product from other East Asian country (intra-regional trade) for at least three consecutive years (a stable trade relation) and the share of import of this product from this given country has to exceed a given threshold (an intensive trade relationship). ${ }^{10)}$ The second production network dummy has a similar definition, but the products are restricted just to parts and components. This restrictive definition is imposed, because it is not possible to distinguish production network imports from consumption imports. In other words, some countries offshore the assemble process and then import the final product in order to add some final value, through activities like packaging, distribution, and marketing, before exporting it to the final consumer. However, we cannot differentiate these cases from cases where the product is imported

10) We define the import intensity by calculating the share of product $k$ imported by country $j$ from country $i$ in period $t$ over all imports of product $k$ by country $j$ in period $t\left(\right.$ share $\left._{i j k t}=\left(\text { Import }_{\text {value }}\right)_{i j k t} j\left(\text { Import }_{\text {value }}\right)_{j k t}\right)$. We assume different levels of threshold varying from at least $5 \%$ to $25 \%$. 
Table 7: Effect of tariff rate on production and non-production network products import tariff evasion

\begin{tabular}{|c|c|c|c|c|c|c|}
\hline & \multicolumn{6}{|c|}{$25 \%$ share threshold } \\
\hline & \multicolumn{2}{|c|}{ Trade Value Gap } & \multicolumn{2}{|c|}{ Quantity Gap } & \multicolumn{2}{|c|}{ Unit Price Gap } \\
\hline & (1) & $(2)$ & (3) & (4) & (5) & (6) \\
\hline \multicolumn{7}{|c|}{ Combined Effects } \\
\hline Non-Production Network & $0.007 * * *$ & $0.006 * * *$ & $0.003 *$ & 0.003 & $0.004 * * *$ & $0.003 * * *$ \\
\hline Production Network 1 & $0.004 *$ & & $0.007 * *$ & & $-0.002 * *$ & \\
\hline Production Network 2 & & 0.006 & & $0.010 * *$ & & $-0.004 * * *$ \\
\hline $\mathrm{R}^{2}$ & 0.078 & 0.072 & 0.076 & 0.071 & 0.114 & 0.114 \\
\hline \multirow[t]{4}{*}{ Observations } & 570087 & 570087 & 570087 & 570087 & 570087 & 570087 \\
\hline & \multicolumn{6}{|c|}{$15 \%$ share threshold } \\
\hline & \multicolumn{2}{|c|}{ Trade Value Gap } & \multicolumn{2}{|c|}{ Quantity Gap } & \multicolumn{2}{|c|}{ Unit Price Gap } \\
\hline & (1) & (2) & (3) & (4) & (5) & (6) \\
\hline \multicolumn{7}{|c|}{ Combined Effects } \\
\hline Non-Production Network & $0.007 * * *$ & $0.006 * * *$ & $0.004 *$ & 0.002 & $0.004 * * *$ & $0.003 * * *$ \\
\hline Production Network 1 & $0.004 *$ & & $0.007 * * *$ & & $-0.002 * *$ & \\
\hline Production Network 2 & & $0.005 *$ & & $0.009 * * *$ & & $-0.005 * * *$ \\
\hline $\mathrm{R}^{2}$ & 0.083 & 0.074 & 0.080 & 0.073 & 0.114 & 0.114 \\
\hline \multirow[t]{4}{*}{ Observations } & 570087 & 570087 & 570087 & 570087 & 570087 & 570087 \\
\hline & \multicolumn{6}{|c|}{$5 \%$ share threshold } \\
\hline & \multicolumn{2}{|c|}{ Trade Value Gap } & \multicolumn{2}{|c|}{ Quantity Gap } & \multicolumn{2}{|c|}{ Unit Price Gap } \\
\hline & (1) & (2) & (3) & (4) & (5) & (6) \\
\hline \multicolumn{7}{|c|}{ Combined Effects } \\
\hline Non-Production Network & $0.008 * * *$ & $0.006^{* * *}$ & $0.004 *$ & 0.002 & $0.004 * * *$ & $0.004 * * *$ \\
\hline Production Network 1 & $0.004 * *$ & & $0.008 * * *$ & & $-0.003 * * *$ & \\
\hline Production Network 2 & & $0.007 * *$ & & $0.01 * * *$ & & $-0.003 * * *$ \\
\hline $\mathrm{R}^{2}$ & 0.093 & 0.077 & 0.088 & 0.076 & 0.114 & 0.114 \\
\hline Observations & 570087 & 570087 & 570087 & 570087 & 570087 & 570087 \\
\hline
\end{tabular}

Note: Standard errors, clustered by product, are listed in brackets. $* * *, * *, *$ denotes significance at the $1 \%, 5 \%$ and $10 \%$ level, respectively. Given a restriction of space, the coefficients of secondary variables are omitted and just the combined effects are presented. 
and consumed in the domestic market.

The first two columns of the top panel of Table $7^{11)}$ contain the results for trade gap considering products with a threshold of at least $25 \%$ share. We observe that a one percentage point increase in the tariff leads to $0.4 \%$ increase in the trade gap for production network products and $0.7 \%$ for non-production network products. However, the result for production network products is statistically significant just at the $10 \%$ level. This result provides a weak evidence that production network products suffer from tariff evasion. Besides this, we observe that production network products are less prone to tariff evasion than non-production network ones. For the more stringent definition a similar tariff increase leads to a growth in the trade gap of $0.6 \%$ for non-production and production network products. Nevertheless, the coefficient for production network products is statistically insignificant, indicating the inexistence of tariff evasion. The next two columns report the coefficients for quantity gap. As already verified, this channel was adopted as the main option to promote tariff evasion in East Asian intraregional trade of parts and components. Observing the coefficients we verify a weak relation between non-production network products and tariff evasion, a coefficient of $0.3 \%$ at the $10 \%$ level, while for production network products a one percentage point increase in tariff rate leads to a $0.7 \%$ increase in quantity gap. When we limit production network products just to parts and components this relation becomes stronger, growing to $1.0 \%$, while the coefficient for non-production network products becomes statistically insignificant. On the opposite side, the coefficients for unit price gap indicate that non-production network products have positive and statistically significant coefficient, while production network ones are negative. This result suggests that production network products are less prone to tariff evasion through unit price misreport than non-production network products.

Relaxing the definition of trade intensity to share thresholds of $15 \%$ and $5 \%$ does not alter much the results. The results confirm that production network products are less prone to tariff evasion and indicate that production network tariff evasion happens mainly through quantity underreport, while in non-production network trade it concentrates on unit price underreport.

\subsection{Comparison with Latin America}

In this subsection we promote a comparison with the Latin American case to verify the existence or not of similar patterns. The objective of this exercise is to confirm if the results found were typical from production network organization or not. The first reason to choose Latin America is because it is also a region composed by few high-income and many middleincome countries. ${ }^{12)}$ Another reason is the existence of many studies in the economics field comparing both regions and their development patterns. The third and most important reason is the fact that, although there are machinery industries in both regions, it is known that differently from East Asia, Latin American regional integration and machinery production networks are still underdeveloped. Thus, if the previous results were attributed to production networks, it is expected that comparing both regions we find import tariff evasion patterns that reveal

11) Given the space constraint, tables 7 to 10 present just the calculated combined effects.

12) According to the available information from World Bank in 2016, Chile and Uruguay are classified as high-income countries; Argentina, Brazil, Colombia, Costa Rica, Ecuador, Panama, Paraguay, Peru, Venezuela (upper-middle-income countries), Bolivia, El Salvador, Guatemala, Honduras and Nicaragua (lower-middle-income countries) are classified as middle-income countries. 
more dissimilitude than similitudes.

The coefficients in Table 8 are higher than the ones in Table 4. In the first column we verify that a one percentage point increase in the tariff leads to $1.1 \%$ increase in the total trade value gap. In the next column we observe a negative and statistically significant coefficient at the $1 \%$ level for similar products, indicating that mislabeling the import as a lower-taxed similar product is also a channel used to evade import tariffs in Latin America. Column 3 reveals that a one percentage point increase in the tariff rate leads to an increase of $1.1 \%$ in the interregional trade gap and $1.3 \%$ in intra-regional case. In the fourth column we observe that separating parts and components from final products the former has lower coefficients. Differently from the East Asian case, the tariff impact on the trade gap is similar for intra and interregional trade, with just inter-regional trade of parts and components suffering slightly less from trade evasion. This indicates that imports origin, if it is inter or intra-regional, does not influence much in the tariff evasion. The next three columns reveal that the majority of the tariff evasion happens through underreport of quantities with intra-regional trade of parts and components being the only exception. Once again the origin of the trade does not affect the final products coefficients that are very similar. Coefficients in column 9 show that just in intra-regional trade there is import tariff evasion. The last column confirms that intra-regional imports suffer more from tariff evasion through misreport of unit prices, with parts and components being the most affected. Inter-regional trade coefficients are statistically significant, but at the $10 \%$ level, while both coefficients for final products are negative and close to zero.

A comparison between East Asian and Latin American results disclose the existence of different patterns in tariff evasion. We observe that coefficients for Latin America are higher than the East Asian ones. We also identify differences in the channels employed to evade tariffs. First, strong evidences of tariff evasion through misclassification were found in Latin America, while the same does not apply to the East Asian case. Second, in Latin America the coefficients for misreport of quantities and unit prices are statistically significant for almost all cases, indicating that all channels were employed to evade tariff. Finally, the most interesting result is the fact that, in general, inter and intra-regional import coefficients do not differentiate much, indicating that the origin of the imports does not matter for tariff evasion. The only exception applies to the fact that unit price misreport is more important than quantity misreport for the intra-regional import of parts and components.

Next, we explore the heterogeneity between different machinery sectors. Tables 9 and 10 contain the results for electric machinery and transport equipment. Once again the coefficients are slightly higher than the East Asian ones. A one percentage point increase in the import tariff leads to $0.9 \%$ increase in the trade gap for electric machinery and $0.9 \%$ for transport equipment. Mislabeling is also a tariff evasion channel utilized in both sectors. For electric machinery, evasion through quantity underreport occurs for the final products independent of the imports origin, while unit price misreport happens for the intra-regional import of parts and components at the $1 \%$ level and inter-regional import of final products at the $10 \%$ level. For transport equipment, evasion through unit price underreport is concentrated in parts and components imports, independent of the origin, while quantity underreport is verified just in interregional imports of final products.

The results in this subsection reveal the existence of different patterns of tariff evasion between East Asia and Latin America. In addition, we observe no clear pattern of differences 
M.S. Chang and C.H. Lin

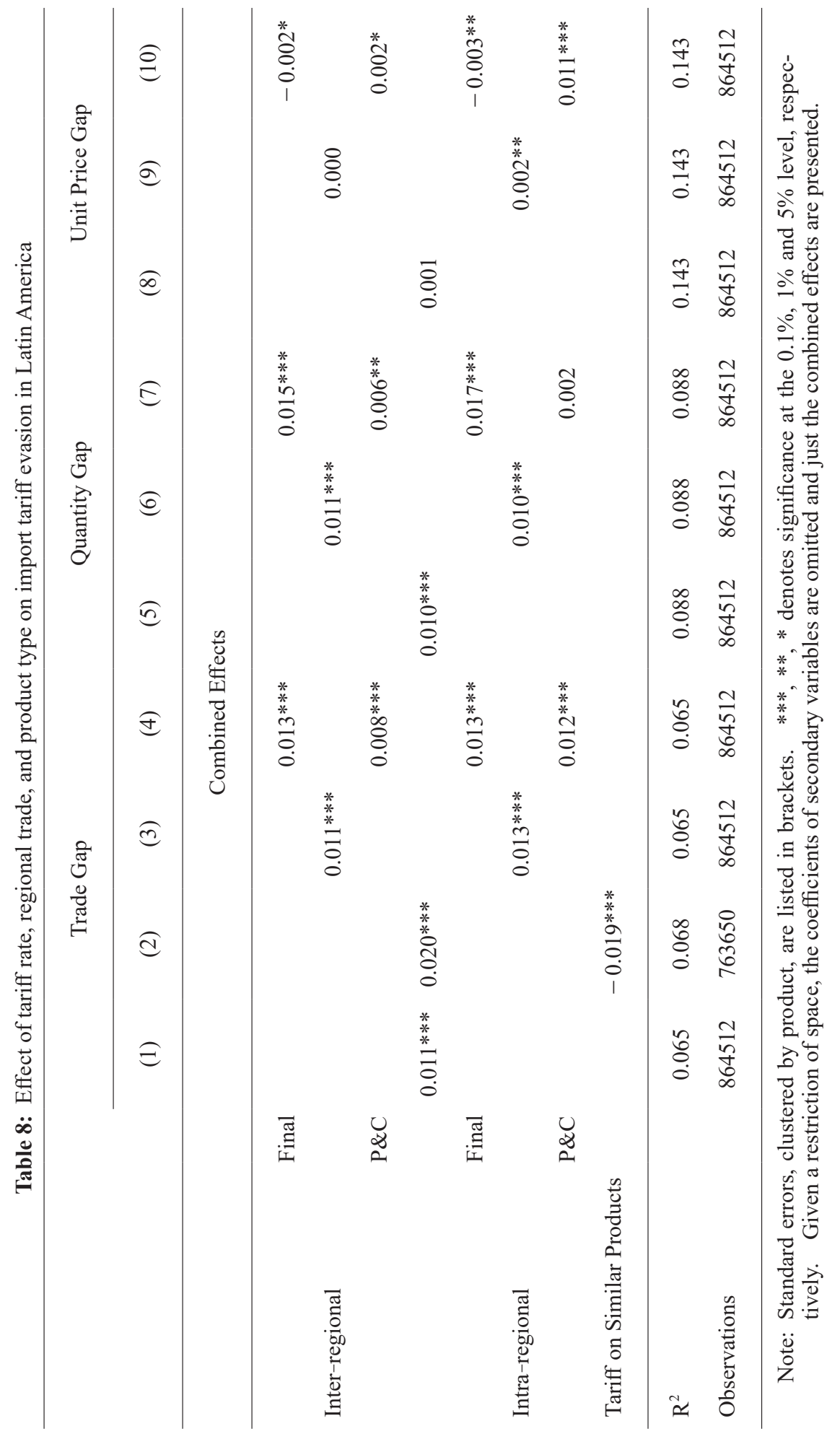


Machinery Production Networks and Import Tariff Evasion

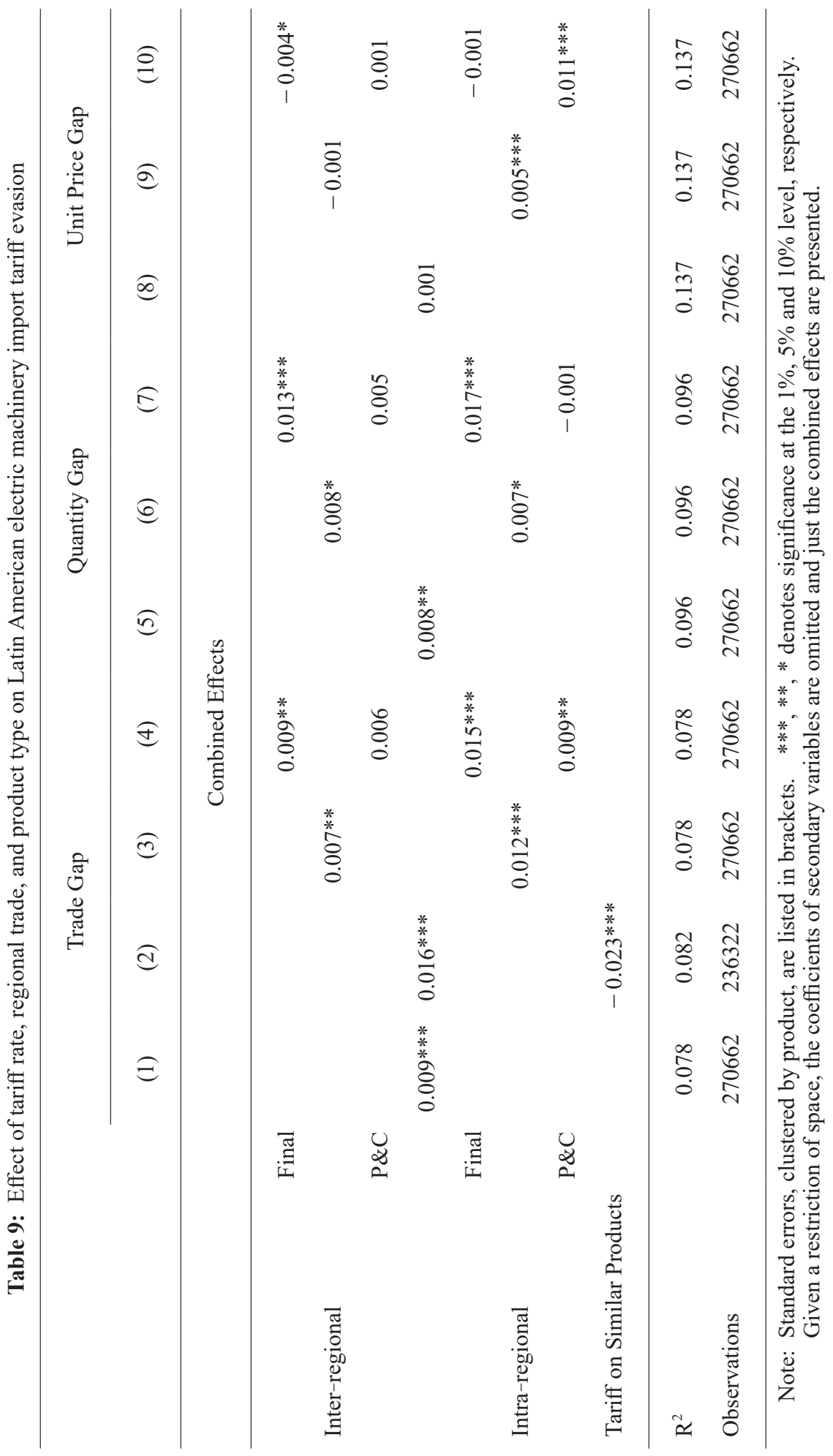


M.S. Chang and C.H. Lin

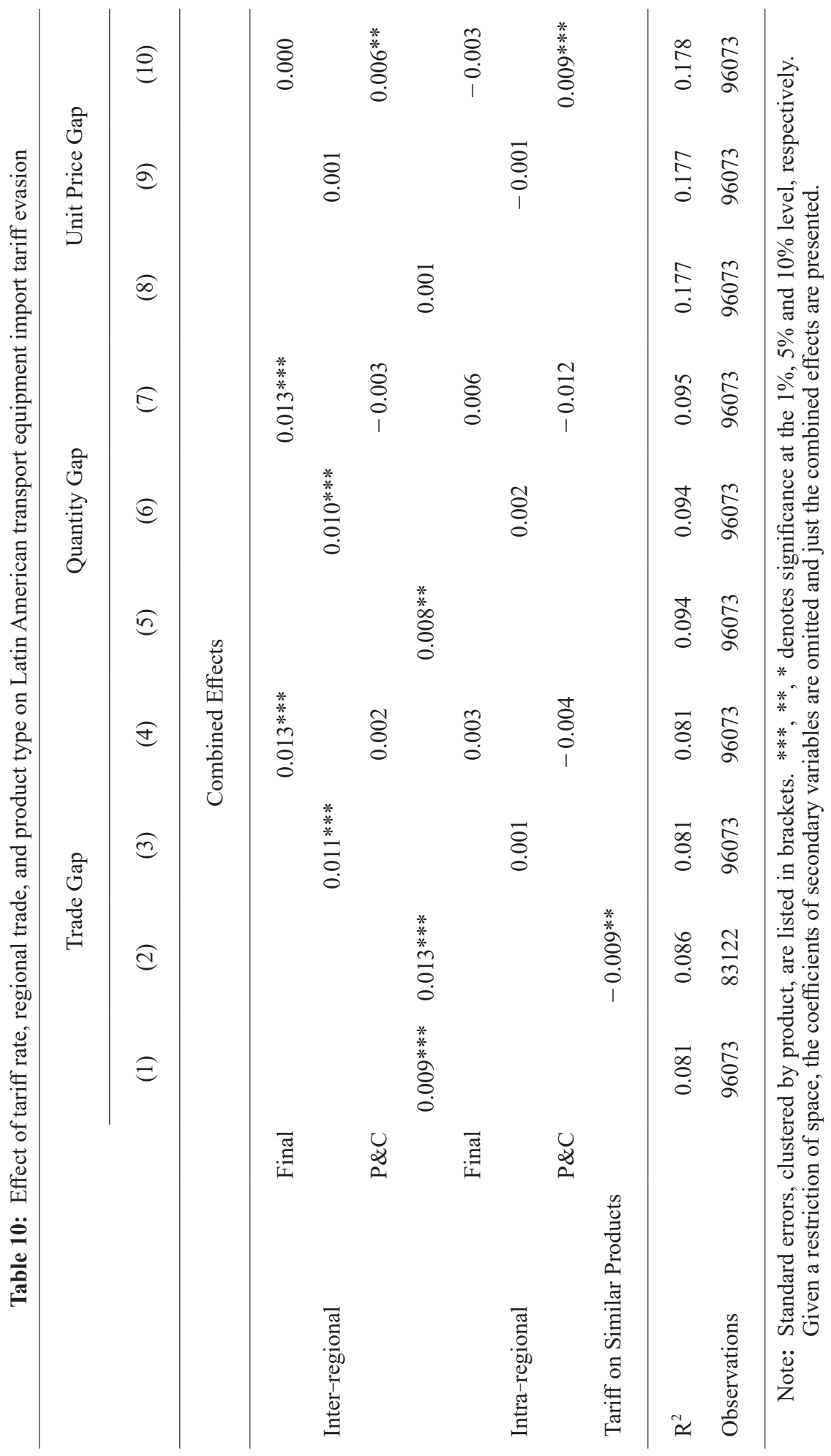


in intra and inter-regional import tariff evasion in Latin America, while in the East Asian case the intra-regional imports are less prone to tariff evasion than the inter-regional ones. Further more, for the Latin American case all channels were employed to evade the import tariff, while in the East Asian case the channels were chosen according to the exporter region and if final products or parts and components were imported.

\section{Concluding remarks}

This paper contributes to the production network and tariff evasion literature by examining if the environment created by the development of machinery production networks affected the levels of import tariff evasion inside and outside this production structure. We followed Fisman and Wei's (2004) approach to estimate the relationship between import tariff rate and import tariff evasion for East Asian countries intra and inter-regional import of machinery products. Differences in tariff evasion between parts and components and final products were considered. We also analyzed the differences in tariff evasion between the main machinery sectors: electric machinery and transport equipment.

The econometric estimations revealed that inter-regional imports are more prone to tariff evasion than intra-regional ones. This evidence is in accordance with the hypothesis that the business environment necessary for the engagement in production networks favor the reduction in tariff evasion. The study of the different channels available to evade tariffs and the heterogeneity between different machinery sectors and product types revealed that quantity underreport is a practice more common in intra-regional imports of electric machinery parts and components. On the opposite side, underreport of unit prices was the main channel employed to evade tariffs in the inter-regional import case.

The employment of dummies with the purpose of improving the data classification in production and non-production network products resulted in very similar outcomes, with production network products been less prone to tariff evasion and having quantity underreport as the main channel employed to evade tariffs. In contrast, the unit price underreport was the main channel employed to evade tariffs in East Asian imports of non-production network products.

Finally, a comparison between the import tariff evasion patterns of East Asia and Latin America revealed that in the latter case, a region where machinery production networks are still underdeveloped, the coefficients are higher than in the former one. Besides this, there were no clear differences between Latin American intra and inter-regional import tariff evasion. Furthermore, for the Latin American case all channels were employed to evade the import tariff. The prevalence of dissimilitude in the tariff evasion patterns between the two regions endorse the hypothesis that the patterns found in the East Asian case are specific of production networks.

\section{Reference}

Athukorala, P. (2011), "Production Networks and Trade Patterns in East Asia: Regionalization or Globalization ?", Asian Economic Papers, vol. 10 (1), pp. 65-95.

Baldwin, R. (2011), " $21^{\text {st }}$ Century Regionalism: Filling the Gap between $21^{\text {st }}$ Century Trade and $20^{\text {th }}$ Century Trade Rules", Centre for Economic Policy Research Policy Insight, vol. 56 (May). 
Bhagwati, J. (1964), "On the underinvoicing of imports", Bulletin of the Oxford University, Institute of Statistics, vol. 2, pp. 389-397.

Bhagwati, J. (1967), "Fiscal policies, the faking of foreign trade declarations, and the balance of payments", Bulletin of the Oxford Bulletin of Economics and Statistics, vol. 29 (1), pp. 61-77.

Bouët, A., and Roy, D. (2012), "Trade Protection and Tax Evasion: Evidence from Kenya, Mauritius and Nigeria”, The Journal of International Trade \& Economic Development, vol. 21 (2), pp. 287-320.

Epaphra, M. (2015) "Tax rates and tax evasion: evidence from missing imports in Tanzania", Business and Economics Journal, vol. 06 (2).

Fisman, R. and Wei, S.J. (2004), "Tax rates and tax evasion: evidence from "missing imports" in China”, Journal of Political Economy, vol. 112 (2), pp. 471-496.

Javorcik, B.S. and Narciso, G. (2008), "Differentiated products and evasion of import tariffs", Journal of International Economics, vol. 76 (2), pp. 208-222.

Javorcik, B.S. and Narciso, G. (2017), "WTO accession and tariff evasion", Journal of Development Economics, vol. 125, pp. 59-71.

Jean, S. and Mitaritonna, C. (2010), "Determinants and pervasiveness of the evasion of customs duties", CEPII, WP, No. 2010-26.

Kellenberg, D. and Levinson, A. (2016), "Misreporting trade: tariff evasion, corruption, and auditing standards", NBER Working Paper, No. 22593.

Kimura, F. and Obashi, A. (2010), International Production Networks in Machinery Industries: Structure and Its Evolution. Working Papers DP-2010- 09, Economics Research Institute for ASEAN and East Asia (ERIA).

Kume, H., Piani, G. and Miranda P. (2011), “Tarifas de importação e evasão fiscal no Brasil”, Economia Aplicada, vol. 15 (1), pp. 65-82.

Levin, J. and Widell, L.M. (2014), "Tax evasion in Kenya and Tanzania: evidence from missing imports", Economic Modelling, vol. 39, pp. 151-162.

Lin, C.H. (2017), The Evasion Gap, Tariff Rates, and International Production Networks. Mimeo.

Mishra, P., Subramanian, A. and Topalova, P. (2008), "Policies, Enforcement, and Customs Evasion: Evidence from India", Journal of Public Economics, vol. 92 (10-11), pp. 1907-1925.

Pritchett, L. and Sethi, G. (1994), "Tariff rates, tariff revenue, and tariff reform: some new facts", World Bank Economic Review, vol. 8 (1), pp. 1-16.

Rauch, J. (1999), "Networks versus Markets in International Trade", Journal of International Economics vol. 48, pp. 7-35.

United Nations Commodity Trade Statistics Database. UN COMTRADE. Retrieved December, 2016, from http://comtrade.un.org/db/

World Integrated Trade Solution (WITS). Retrieved December, 2016, from http://wits.worldbank.org/ 
Machinery Production Networks and Import Tariff Evasion

Table A.1: Country List by Regions

\begin{tabular}{|c|c|c|c|c|c|}
\hline Region & Name & Region & Name & Region & Name \\
\hline NAFTA & Canada & EU & Malta & ROW & Cote d'Ivoire \\
\hline NAFTA & Mexico & $\mathrm{EU}$ & Netherlands & ROW & Croatia \\
\hline NAFTA & USA & $\mathrm{EU}$ & Poland & ROW & Egypt \\
\hline East Asia & Brunei Darussalam & $\mathrm{EU}$ & Portugal & ROW & Georgia \\
\hline East Asia & Cambodia & EU & Romania & ROW & Ghana \\
\hline East Asia & China & EU & Slovakia & ROW & Iceland \\
\hline East Asia & China, Hong Kong & EU & Slovenia & ROW & India \\
\hline East Asia & Indonesia & EU & Spain & ROW & Israel \\
\hline East Asia & Japan & EU & Sweden & ROW & Jamaica \\
\hline East Asia & Malaysia & $\mathrm{EU}$ & United Kingdom & ROW & Kyrgyzstan \\
\hline East Asia & Myanmar & Latin America & Argentina & ROW & Mali \\
\hline East Asia & Philippines & Latin America & Bolivia & ROW & Mauritius \\
\hline East Asia & Rep. of Korea & Latin America & Brazil & ROW & Morocco \\
\hline East Asia & Singapore & Latin America & Chile & ROW & New Zealand \\
\hline East Asia & Thailand & Latin America & Colombia & ROW & Niger \\
\hline East Asia & Vietnam & Latin America & Costa Rica & ROW & Nigeria \\
\hline EU & Austria & Latin America & Ecuador & ROW & Norway \\
\hline EU & Bulgaria & Latin America & El Salvador & ROW & Oman \\
\hline $\mathrm{EU}$ & Czech Rep. & Latin America & Guatemala & ROW & Rep. of Moldova \\
\hline $\mathrm{EU}$ & Cyprus & Latin America & Honduras & ROW & Russian \\
\hline $\mathrm{EU}$ & Denmark & Latin America & Nicaragua & ROW & Saudi Arabia \\
\hline EU & Estonia & Latin America & Panama & ROW & Senegal \\
\hline EU & Finland & Latin America & Paraguay & ROW & Sudan \\
\hline EU & France & Latin America & Peru & ROW & Switzerland \\
\hline EU & Germany & Latin America & Uruguay & ROW & Rep. of Macedonia \\
\hline $\mathrm{EU}$ & Greece & Latin America & Venezuela & ROW & Tunisia \\
\hline $\mathrm{EU}$ & Hungary & ROW & Albania & ROW & Turkey \\
\hline EU & Ireland & ROW & Algeria & ROW & Uganda \\
\hline $\mathrm{EU}$ & Italy & ROW & Australia & ROW & Ukraine \\
\hline EU & Latvia & ROW & Azerbaijan & ROW & Tanzania \\
\hline $\mathrm{EU}$ & Lithuania & ROW & Cameroon & ROW & Zambia \\
\hline
\end{tabular}

